\title{
The Role of FNAC in Diagnosis of Breast Disease at Different Ages - 208 Cases
}

\author{
SMSA CHAUDHURYa ${ }^{\mathrm{a}}$ MK ALAM ${ }^{\mathrm{b}}$, MS HAQUEc
}

\begin{abstract}
Summary:
All breast lesions are not malignant, and all the benign lesions do not progress to cancer; however the accuracy of diagnosis can be increased by a combination of preoperative tests. About 30\% of women suffer from breast disease in their lifetime. The main objectives are to explore the role of FNAC in diagnosis of breast disease at different ages. Fine needle aspiration cytology (FNAC) has become a critical component in the investigation of palpable breast masses.
\end{abstract}

Total 208 cases included in this study at Comilla. The data was formulated and analyzed by SPSS-12. 79(37.98\%) cases were at the age of 21-30 years and next one was 11-20 years

Introduction:

Breast, a sign of womenhood and fertility has been a subject for clinicians from the time medicine is being practiced. Breast diseases are the most common ailment from which women suffer throughout the world. About $30 \%$ of women suffer from breast disease in their lifetime ${ }^{1}$.

The palpable breast lesion is a common problem at the surgical outpatient clinics. The aim in management is to exclude malignant disease and in this aspect, fine needle aspiration cytology (FNAC) plays an important role ${ }^{2}$.

Fine needle aspiration cytology is an excellent safe and cost effective diagnostic procedure. One can get on site

a. Dr. S.M. Shafiul Azam Chaudhury, FCPS (Surgery), Junior consultant surgery, Sadar Hospital, Comilla.

b. Dr. Md. Khurshid Alam, M.Phil.(Pathology), Lecturer,Dept. of Pathology, Comilla Medical College, Comilla.

c. Dr. Md. Serajul Haque, FCPS (Surgery), MS (Urology), Associate Professor, Dept. of Surgery, Comilla Medical College Hospital, Comilla.

Address of Correspondence: Dr.S.M.Shafiul Azam Chaudhury, Junior consultant surgery, Sadar Hospital, Comilla, E-mail: mithudr21@yahoo.com Mobile:01711375638

Received: 9 October, 2011

Accepted: 11 June, 2012 which was 48(23.07\%). Among them 40(19.23\%) cases were malignant and $168(80.77 \%)$ cases were benign in nature. The incidence of malignancy was increased with relation to age. As the age is more chance of malignancy is more. In benign types fibroadenoma was the common disease then the duct cell carcinoma, fibrocystic change, suppurative inflammation respectively. The findings were $43.75 \%$, $19.23 \%, 18.27 \%$ and $8.65 \%$.

In conclusion, fine needle aspiration cytology, for diagnosis of breast lump can reduce the number of open biopsy and surgery.

(J Bangladesh Coll Phys Surg 2012; 30: 137-140)

immediate report with minimal cost using inexpensive equipment and a simple technique. The most significant advantage of FNAC is the high degree of accuracy, rapid results, and a less invasive procedure than a tissue biopsy. FNAC of the breast can reduce the number of open breast biopsies. ${ }^{3-6}$

The triple diagnostic method (consisting of clinical evaluation, mammography and fine needle aspiration cytology) gives a precise diagnosis and reduces the risk of a missed diagnosis of breast cancer to $<1 \%{ }^{7}$. The aim of this study is to find out the common causes of breast lump at different ages and offer treatment.

\section{Materials and Methods:}

This study was carried out at Comilla in different clinics and hospitals. It was undertaken from 01.01.2010 to 31.12.2010.All breast lump of female patient were included in this study. Data was collected randomly as per inclusion and exclusion criteria. The age of the patient and FNAC report were recorded for analysis of data. Data was analyzed by manually and by SPSS-12(SPSS = Statistical Programmed for Scientific Study). The results were plotted in tables, charts and graphs. 


\section{Inclusion criteria:}

1. All patients presented with breast lump.

2. All female patients of at any age.

\section{Exclusion criteria:}

1. Male patient with breast disease.

2. Lump negative patients.

3. Patient with histopathological diagnosis of malignancy.

\section{Results:}

\section{Table-I}

\begin{tabular}{lcc}
\multicolumn{3}{c}{ Age distribution } \\
Age of the patient & Number of cases & Percentages \\
\hline $11-20$ & 48 & $23.07 \%$ \\
$21-30$ & 79 & $37.98 \%$ \\
$31-40$ & 39 & $18.75 \%$ \\
$41-50$ & 27 & $12.98 \%$ \\
$51-60$ & 11 & $5.29 \%$ \\
$61-70$ & 03 & $1.44 \%$ \\
$71-80$ & 00 & 00 \\
$81-90$ & 01 & $0.48 \%$ \\
\hline Total & 208 & $100 \%$ \\
\hline
\end{tabular}

The total number of cases was 208. Most of the patients were in the age group 11-50 years. Among them 79 cases were present in 20-30 years age group. This data consists of both benign and malignant disease. Only one case was at 81-90 years.

\section{Table-II}

\begin{tabular}{lcc} 
& \multicolumn{2}{c}{ Disease type } \\
& Number of cases & Percentages \\
\hline Benign & 168 & $80.77 \%$ \\
Malignant & 40 & $19.23 \%$ \\
\hline Total & 208 & $100 \%$ \\
\hline
\end{tabular}

In Table II shows the benign and malignant diseases of the breast. Most of the cases were benign, which was 168 cases. But malignant disease was 40 cases only.

\section{Table-III}

\section{Comparison of benign and malignant disease of} different age (cross table test).

\begin{tabular}{lccc} 
Age & Benign & Malignant & Total \\
\hline $11-20$ & $47(97.92 \%)$ & $01(2.08 \%)$ & 48 \\
$21-30$ & $75(94.94 \%)$ & $04(5.06 \%)$ & 79 \\
$31-40$ & $29(74.36 \%)$ & $10(25.64 \%)$ & 39 \\
$41-50$ & $14(51.85 \%)$ & $13(48.15 \%)$ & 27 \\
$51-60$ & $03(27.27 \%)$ & $08(72.73 \%)$ & 11 \\
$61-70$ & 0 & $03(100 \%)$ & 03 \\
$81-90$ & 0 & $01(100 \%)$ & 01 \\
\hline Total & 168 & 40 & 208 \\
\hline
\end{tabular}

In correlation of benign and malignant disease with age showed that the number of malignant disease was increased with increasing age. Benign disease of breast was more in younger ones. Maximum benign disease were in the age of 21-30 years which was about 75 . Older at the age of 81-90 years single malignant disease was present.

\section{Table-IV}

\section{Types of disease}

\begin{tabular}{lcc} 
Disease & Number of cases & Percentages \\
\hline Fibroadenoma & 91 & $43.75 \%$ \\
Fibrocystic change & 38 & $18.27 \%$ \\
Duct cell carcinoma & 40 & $19.23 \%$ \\
Suppurative Inflammation & 18 & $8.65 \%$ \\
Granulomatous mastitis & 09 & $4.32 \%$ \\
Galactocele & 09 & $4.32 \%$ \\
Lipoma & 02 & $0.96 \%$ \\
Accessory breast tissue & 01 & $0.48 \%$ \\
\hline Total & 208 & $100 \%$ \\
\hline
\end{tabular}

The commonest disease of breast was fibroadenoma which was about 91 cases. Duct cell carcinoma was the malignant disease, it was about 40 cases and 38cases had fibrocystic change. 
Table-V

\begin{tabular}{lccc}
\multicolumn{4}{c}{ Test statistics } \\
& Age & Disease type & Disease \\
\hline Chi-square & 159.702 & 78.769 & 299.894 \\
df & 06 & 01 & 8 \\
Asymp. Significance & .000 & .000 & .000 \\
\hline
\end{tabular}

\section{Discussion:}

Total 208 patients were included in this study. All patients were female and FNAC done in all cases and reports were interpretated in a tabulated form.

Age distribution of the disease was 48, 79, 39, 27, 11, 03 and 01 cases at different age distribution. The breast disease was more common between the age of 21-30 years and was commoner among 11-20 years age group. Another study showed that the distribution was 23, 76, 166, 86, 53, 16 and 5 cases respectively. This disparity due to more number of cases in this study. ${ }^{8}$

Among the 208 cases 168(80.77\%) cases were benign and 40(19.23\%) cases were malignant. The benign cases were more than the malignant cases.Tiwari $\mathrm{M}$. found only $6.6 \%$ cases were malignant and others were benign in out of 91 cases. ${ }^{9}$ Usually the percentage of benign is $80 \%$ and that of malignant was $20 \%{ }^{13}$.

In comparison of malignancy at different age showed that the number of malignancy with advancement of age of the patients. Here 01 (one) case was found at the age of 11-20 years but at 41-50 years 13 cases were malignant out of 27 cases. At the age of 61-70 years almost $100 \%$ cases were malignant. Carcinoma of the breast is extremely rare below the age of 20 years about, thereafter; the incidence steadily rises so that by the age of 90 years nearly $20 \%$ of women are affected ${ }^{10}$.

In type of disease, maximum disease was benign in nature. Among them fibroadenoma was the most common which was 91(43.75\%) and it correlates with other studies ${ }^{8.9}$.Malignant breast lump present in $40(19.23 \%)$ of cases. In different studies it was $6.6 \%$ ${ }^{9}$ and a recent study in Pakistan showed breast cancer only in $6.9 \%{ }^{11}$. A recent study by Yousuf ${ }^{12}$ in Rawalpindi also observed 21\% cancer in their study.
Next suppurative inflammation and galactocele present in 18(8.65\%) and 09(4.32\%). Tiwari M. found breast abscess in $6.6 \%$ and galactocele in $5.5 \%$ of cases ${ }^{9}$. Tuberculous mastitis was present in $4.32 \%$ of cases and showed in breast tuberculosis in 2.3\% of cases ${ }^{8}$.

\section{Conclusion:}

This prospective study was done at Comilla district with sample size was 208. FNAC was done in all female patients having breast lump and male patients were excluded from the study.

The commonest age of breast disease was 21-30 years which was 79(39.98\%) of cases. The next commoner age group was $11-20$ years, it was about $48(23.07 \%)$ and 31-40 years 39 (18.75\%). 80\% cases were suffering from benign disease and rest of the patient were malignant in nature.

The comparison of disease at different ages showed that the percentages of malignancy increases with the increasing of age. At the age of 11-20 years most of the cases were benign and only one case was malignant but at the age of $51-60$ years $100 \%$ of cases become malignant.

The type of diseases was variable. Most common was fibroadenoma $43.75 \%$ (91) and the next one was fibrocystic change which was 38(18.27\%) cases. Duct cell carcinoma was found in 40(19.23\%) cases and tuberculosis in breast disease was 09 (4.32\%) of cases.

Small sample size does not depict the picture of whole nation. A large scale study in required for further evaluation of disease.

\section{References:}

1. Russel RCG, Williams NS, Bulstrode CJK. Breast: Bailey and Loves, Short Practice of Surgery; $23^{\text {rd }}$ ed. London: Arnold, 2000: 749-72.

2. Nicosia SV, Williams JA, Horowitz SA et al.Fine Needle aspiration biopsy of palpable breast lesion. Review and statistical analysis of 1875 cases. Surg.Oncol.1993;2:145-60.

3. Hindle WA, Payne PA $<$ and Pan EY. The use of fine needle aspiration in the evaluation of persistent palpable dominant breast masses; American Journal Of Obstetrics and Gynaecology, vol. 168; no.61; pp.1814-1819; 1993. 
4. Lee HC, Ooi RT, Poh WT and Wang CY. Impact of inadequate fine needle aspiration cytology on outcome of patient with palpable breast lesion; Australian and New Zealand journal of surgery; vol.70;no.9;,pp656-659;2000.

5. Khatun N, Tarek-al-naser, Enam S, Hussain M, and Begum M. correction of fine needle aspiration cytology and its histopathology in diagnosis in breast lumps; Bangladesh Research Council Bulletin;vol.28;no.2;pp.77-81;2002.

6. He Q, Fan X, Yuan T et al. Eleven years of experience reveals that fine needle aspiration cytology is still a useful method for preoperative diagnosis of breast carcinoma breast; vol.16; no.3; pp303-306; 2007.

7. Jay H, Monica M, Marcos L, Samuel H. Diagnosis of the breast; Philadelphia: Lippincott - Raven; 1996; ch.5.

8. Bukhari MH, Arshad M, Jamal S. et al. Use of fine needle aspiration in the evaluation of breast lumps; SAGE-Hindani access to research pathology research international vol.2011 article ID 689521.

9. Tiwari M. Role of fine needle aspiration cytology in diagnosis of breast lumps; Katmandu University Medical Journal;vol.5; no.2; issue 18,215-217:2007.

10. Williams NS, Bulstrpde CJK, O’Connell PR. Breast: Bailey and loves: short practice of surgery; 25th ed; Hodder: Arnold; 2008:837.

11. Siddique K, Rasool MI. Pattern of breast diseases - preliminary report of breast clinic. JCPS2000; 11(8):497-500.

12. Yousuf A, khan JS. et al. Level of awareness about breast cancer among females presenting to a general hospital in Pakistan; JCPS 2001; 11(3); 131-5.

13. Ahmed S, Raza SZ and Khan TM. To evaluate the accuracy of FNAC in palpable breast lump at breast clinic of Abbasi Shaheed Hospital, Karachi; Pak. J. Surg. 2010; 26(2): 111-117. 